\title{
Distribution patterns of meiofauna on a tropical macrotidal sandy beach, with special focus on nematodes (Caixa d'Água, Amazon Coast, Brazil)
}

\author{
Erivaldo Baia ${ }^{1 *}$, Virag Venekey ${ }^{l}$
}

\begin{abstract}
${ }^{1}$ Universidade Federal do Pará, Grupo de Estudos de Nematoda Aquáticos, Laboratório de Pesquisa em Monitoramento Ambiental Marinho (Av. Augusto Corrêa, 01. Guamá - Belém - Pará, Brazil. CEP: 66075-110)

*Corresponding author: eri.baia@yahoo.com.br
\end{abstract}

\section{Abstract}

Spatial distribution patterns (both horizontal and vertical) of meiofauna, with special focus on nematodes, on a tropical macrotidal beach across different climatic periods were analyzed in this study. Samplings were carried out at five stations in the intertidal zone in June (rainy season) and December (dry season), 2011. At each station, three samples were taken using a corer with $3 \mathrm{~cm}$ diameter, which was thrust $10 \mathrm{~cm}$ into the substrate and stratified in $0-2,2-5$, and $5-10 \mathrm{~cm}$. Meiofauna was comprised of 16 groups and Nematoda was the dominant. Meiofauna density during rainy season was higher at the central intertidal station and during dry season it was lower near the high tide mark, followed by an increasing trend towards the low tide mark. Meiofauna was more concentrated in the upper sediment layer during rainy season. However, during dry season, the highest density occurred in the lower sediment layer at both stations near the high tide mark. Nematoda association was comprised of 72 genera, with Daptonema and Theristus (both from the family Xyalidae) as the dominant ones in most stations and strata. The genera richness and diversity increased towards the low tide mark, with lower richness in the upper stratum at most stations. Non-selective deposit-feeders predominated during rainy season, while at dry season there was an alternation of dominance between non-selective deposit-feeders and epistrate feeders. Significant differences were found in the meiofauna community, as well as in the Nematoda association in regard to the months, stations, and sediment layers. The distribution patterns of interstitial organisms found in this study, in part, follow what is already known for microtidal beaches but other differential aspects were observed even if compared to environments of macrotidal beaches in temperate regions.

Descriptors: Meiobenthos, Spatial distribution, Temporal distribution, Macrotidal, Continental island, Amazon Region.

\section{INTRODUCTION}

Meiofauna is a community of approximately 30 phyla that inhabit the interstices of aquatic sediments (Giere, 2009) and among them Nematoda stand out as the invertebrates with the highest abundance, with a number of species that is higher in magnitude than any other benthic taxon (Heip et al., 1982; Hodda, 2007). The distribution patterns of meiofauna are horizontally and vertically variable, and depend on a combination of physical and chemical environmental conditions, such as temperature, salinity (Olafsson, 1991), and desiccation (Jansson, 1968).

In beach environments, meiofauna generally have a highest horizontal diversity near the low tide mark, while its lowest diversity is found close to the high tide mark.

Submitted on: 13/November/2018

Approved on: 5/May/2019

http://dx.doi.org/10.1590/S1679-87592019023006701
On the other hand, density does not follow this same pattern and frequently the highest abundance is found in the middle intertidal, although nematodes are known to be very resistant occurring with high densities in all intertidal region (Giere, 2009). Vertically, sandy beach organisms have preference for upper sediment layers (McLachlan, 1977), nematodes are mainly distributed close to the surface, moving to deeper layers during high tides and subsequently returning (Platt, 1977), but in some exposed beaches they can be found even $1 \mathrm{~m}$ deep (Heip et al., 1985). These patterns, however, are well established on microtidal beaches of temperate and tropical regions. For macrotidal beaches of tropical regions the major limiting factor to understanding them is the scarcity of studies on meiofauna structure.

Temporal variation on meiofauna also occurs in short(related to tidal cycle and changes in sediment moisture), medium- (on a daily basis, related to changes in temperature), 
and long term (related to seasons of the year) (McLachlan and Brown, 2006). Seasonal changes in abundance and composition of meiofauna communities in coastal environments have been clearly observed in several studies, and are related to annual variations in temperature and food availability (Heip et al., 1985; Coull, 1999; Albuquerque et al., 2007). For instance, Nematoda are known to have higher abundance in the hottest period of the year in temperate regions (Coull, 1988) but, there is still no well-established pattern described to tropical regions. The few existing studies in these regions indicate rainfall as the major structuring factor of meiofauna and nematofauna (Pattnaik and Rao, 1990; Ingole and Parulekar, 1998; Gomes and Rosa-Filho, 2009; Venekey et al., 2014).

In an attempt to understand distribution and structure of Nematoda associations on beaches, several studies have been conducted both on horizontal distribution (Nicholas and Hodda, 1999; Gheskiere et al., 2002; Gheskiere et al., 2004; Gingold et al., 2010; Maria et al., 2013) and on vertical distribution (Sharma and Webster, 1983; Maria et al., 2012; Maria et al., 2018). However, the studies focusing on horizontal and/or vertical distribution across climatic periods are still limited (Sharma and Webster, 1983; Nicholas and Hodda, 1999; Armenteros et al., 2009; Gingold et al., 2010). In addition, most part of this knowledge came from studies on microtidal beaches, while macrotidal areas remain virtually unknown (Gheskiere et al., 2002; Gheskiere et al., 2004; Gingold et al., 2010; Maria et al., 2012; Maria et al., 2013; Maria et al., 2018). Even less is known about climatic seasonality, except for Gingold et al. (2010), who studied El Tornillal beach in the Gulf of California (Mexico) for two distinct periods.

The Amazon coast represent 35\% of the Brazilian littoral and presents a highly peculiar dynamics compared to other regions worldwide, such as: semi-diurnal macrotides, high discharge of rivers and the presence of moderate wave energy modulated by sandy bars and rips (Oliveira et al., 2014). All region is subject to spatial and temporal dynamics unrivalled worldwide due to factors such as the climate governed by the Intertropical Convergence Zone (ITCZ). One of the main consequences of the ITCZ is the period of rainfalls that occurs more intensively from January to April (Moraes et al., 2005). The periodicity of rainfalls influences the flood regime in all tributaries of Amazon River and consequently generates seasonal changes in its discharge.
These phenomena together with constant trade winds, strong coastal currents and wide tidal breadths (macrotides) cause high reworking and sediment erosion, and have a direct influence on all Amazon region (Souza Filho et al., 2009).

The aim of the present study is to characterize spatial distribution patterns (both horizontal and vertical) of meiofauna, with special focus on nematodes, on an Amazonian macrotidal tropical beach (Caixa d'Água, Algodoal Island, Brazil), across dry and rainy periods.

\section{MATERIAL AND METHODS}

Caixa d'Água beach is located in the northwestern region of Algodoal-Maiandeua Island, approximately $150 \mathrm{~km}$ away from Belém (capital city of Pará state). The island is located in the northern coast of Brazil (47'32'05" to $47^{\circ} 34^{\prime} ' 12^{\prime \prime} \mathrm{W}$ and $0^{\circ} 34^{\prime} 45^{\prime \prime}$ to $0^{\circ} 37^{\prime} 30^{\prime}$ " S) and is limited by the Atlantic Ocean to the North, the Maracanã Bay to the East, the Marapanim Bay to the West, and Mocoóca stream to the South (Prost, 1994) (Figure 1). Climate in the Amazon region is tropical humid and seasonal changes results from the InterTropical Convergence Zone (ITCZ), with mean annual temperature of $27.7^{\circ} \mathrm{C}$. There are two well defined seasons, rainy from January to August, and dry, from September to December (Moraes et al., 2005). The annual mean precipitation ranges from 2300 to $2800 \mathrm{~mm}$, with $73 \%$ of it occurring from January to April (Moraes et al., 2005). Caixa d'Água is morphologically classified as a low-tide terrace beach (Rosa-Filho et al., 2011) and has $200 \mathrm{~m}$-long intertidal zone. Surface sediment on Caixa d'Água is dominated by very fine sand (RosaFilho et al., 2011) and tidal amplitude in the area ranges from $4 \mathrm{~m}$ to $6 \mathrm{~m}$ (macrotide), with a semi-diurnal cycle (Ataide et al., 2014).

Samplings were carried out in June (representing rainy period) and December (representing dry period), 2011 , in the intertidal zone using a stratified sampling design. A transect perpendicular to the spring tide mark was outlined and five stations $50 \mathrm{~m}$ apart from each other were sampled. The first station (S1) was located close to the high tide mark and the last one (S5) was located near the low tide mark. Three samples were taken from each station using a corer with $3 \mathrm{~cm}$ diameter, thrust $10 \mathrm{~cm}$ in the substrate and stratified in $0-2$, $2-5$, and $5-10 \mathrm{~cm}$, and were subsequently fixed in $4 \%$ saline formalin. Surface temperature of substrate was determined at each station using a soil thermometer. 

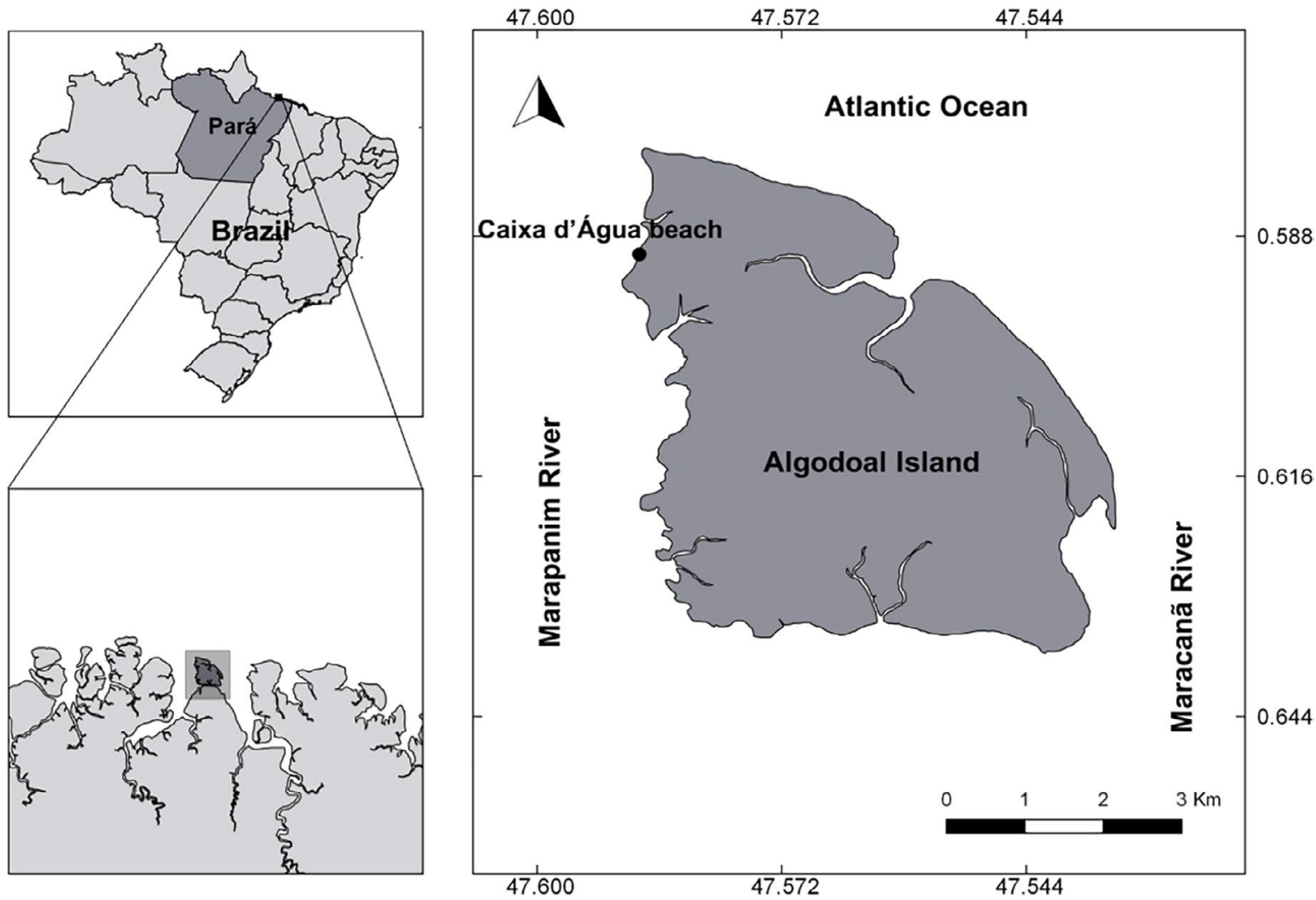

Figure 1. Map indicating the Caixa d'Água beach, Algodoal Island, Amazon Coast, Brazil.

Surface water salinity was determined using a manual refractometer. In addition, rainfall data were obtained from the National Institute of Meteorology (INMET) considering the climatological station of Marudá, a district located approximately $8 \mathrm{Km}$ away from Algodoal Island, which belongs to the municipality of Marapanim.

Meiofauna was extracted from the sediment in the laboratory using manual elutriation as suggested by Elmgren (1973), and the supernatant was passed through 0.044 to $0.5 \mathrm{~mm}$-mesh sieves. In order to count meiofauna groups, the sample retained in the $0.044 \mathrm{~mm}$ sieve was stained with Rose Bengal and the animals were counted in a Dollfus plate with the help of a stereoscope microscope. The 50 first Nematoda of each sample were removed, diaphanized, and mounted on permanent slides following the protocol by De Grisse (1969).

Nematoda individuals were identified at the genus level under optical microscope and using the pictorial key by Warwick et al. (1998), as well as specific bibliography from the Marine Biology Section of Ghent University (Belgium) and from Nemys website (Vanaverbeke et al., 2016). The genera found were grouped in four trophic types based on oral cavity structure according to Wieser (1953): 1A - selective deposit-feeders without oral cavity,
1B - non-selective deposit-feeders with wide oral cavity without teeth, $2 \mathrm{~A}$ - epistrate feeders with oral cavity with small teeth, and 2B - predators/omnivores with wide oral cavity with strong teeth and/or mobile mandibles. The classification proposed by De Ley and Blaxter (2004) was adopted to make the taxonomic list.

For each sample, density (ind./10 $\left.\mathrm{cm}^{2}\right)$, richness (S), evenness (J') and diversity $\left(\mathrm{H}^{\prime} \log _{2}\right)$ of the meiofauna community and Nematoda association were calculated. Cochran tests were used to check the homogeneity of variances, and where required, data were $\log$ transformed (x +1 ). Differences in descriptors of meiofauna community and Nematoda association between periods (rainy and dry), stations (S1, S2, S3, S4, and S5), and sediment layers (0$2,2-5$, and $5-10 \mathrm{~cm})$ were tested using an analysis of variance (factorial ANOVA). Temperature was also analyzed between periods with an ANOVA. An a posteriori Tukey's test was performed when significant differences between factors were detected. PERMANOVA was applied to assess differences in meiofauna communities and Nematoda associations after data transformed to $\log (\mathrm{x}+1)$ and using the Bray Curtis index. Pairwise a posteriori comparisons were performed when significant differences were detected. 
The formation of groups due to the effect of factors in community and association structures were visualized using a non-metric Multidimensional Ordination (nMDS). The contributions of each meiofauna group and Nematoda genus to dissimilarity between periods, stations, and sediment layers were analyzed using the percentage of similarity (SIMPER). The significance level adopted for all analyses was 0.05 . Statistical analyses were performed using the STATISTICA 8, PRIMER 6, and PERMANOVA+ programs.

\section{RESULTS}

\section{ENVIRONMENTAL PARAMETERS}

Salinity was $23 \mathrm{ppt}$ in the rainy period and 36 in the dry period. Temperature varied between periods $(p<0.05)$ with mean value of $29.8^{\circ} \mathrm{C}$ and $33.0^{\circ} \mathrm{C}$ in the rainy and dry periods, respectively. Among stations temperature varied from $29^{\circ} \mathrm{C}$ at $\mathrm{S} 5$ to $30^{\circ} \mathrm{C}$ at the other stations in the rainy period and from $32^{\circ} \mathrm{C}$ at $\mathrm{S} 4$ to $34^{\circ} \mathrm{C}$ at $\mathrm{S} 1$ and $\mathrm{S} 3$ in the dry period. Rainfall was $126 \mathrm{~mm}$ in June (rainy period) and $19 \mathrm{~mm}$ in December (dry period) (INMET, 2018).

\section{Meiofauna}

Meiofauna was represented by 16 groups (Acari, Bivalvia, Collembola, Copepoda, Gastrotricha, Kinorhyncha, Insecta Larvae, Mollusca, Nauplius, Nematoda, Oligochaeta, Ostracoda, Polychaeta, Rotifera, Tardigrada, and Turbellaria). The rainy period presented one taxon more (14) than the dry period (13). Collembola, Kinorhyncha, and Oligochaeta were exclusive to the rainy period, while Gastrotricha and Mollusca were only found in the dry period.

Meiofauna density, richness, and diversity significantly varied among stations and sediment layers, but not between periods (Table 1). Significant variation in density, richness and diversity were also found considering interactions of the factors (except period x sediment layers for richness). On the other hand, evenness significantly varied only among sediment layers and interactions of some factors. In the rainy period density was higher at the central station (S3) (2553.74 ind. $\left./ 10 \mathrm{~cm}^{2}\right)$, although the closest station to the high tide mark (S1) had a similarly high density. The lowest density was found at S4 (288.11 ind. $\left./ 10 \mathrm{~cm}^{2}\right)$.

Table 1. Results of the factorial ANOVA evaluating the significance of differences in the descriptors of meiofauna community and Nematoda associations at Caixa d'Água beach. Asterisks represent significant differences $(p<0.05)$.

\begin{tabular}{|c|c|c|c|c|c|c|c|c|c|}
\hline \multirow[b]{2}{*}{ Factors } & \multirow[b]{2}{*}{ df } & \multicolumn{2}{|c|}{ Density } & \multicolumn{2}{|c|}{ Richness } & \multicolumn{2}{|c|}{ Evenness } & \multicolumn{2}{|c|}{ Diversity } \\
\hline & & $\mathrm{F}$ & $p$ & $\mathrm{~F}$ & $p$ & $\mathrm{~F}$ & $p$ & $\mathrm{~F}$ & $p$ \\
\hline \multicolumn{10}{|l|}{ Meiofauna } \\
\hline Periods (P) & 1 & 1.61 & 0.209 & 0.80 & 0.374 & 1.40 & 0.240 & 0.35 & 0.551 \\
\hline Stations (Sta) & 4 & 11.09 & $0.000 *$ & 3.26 & $0.017 *$ & 0.90 & 0.467 & 2.56 & $0.046^{*}$ \\
\hline Layers (Lrs) & 2 & 140.09 & $0.000 *$ & 34.63 & $0.000 *$ & 14.91 & $0.000 *$ & 31.05 & $0.000 *$ \\
\hline P x Sta & 4 & 24.09 & $0.000^{*}$ & 5.78 & $0.000 *$ & 2.19 & 0.081 & 5.79 & $0.000 *$ \\
\hline Px Lrs & 2 & 19.50 & $0.000^{*}$ & 2.26 & 0.112 & 0.16 & 0.853 & 3.71 & $0.030^{*}$ \\
\hline Sta $x$ Lrs & 8 & 3.93 & $0.000 *$ & 5.42 & $0.000 *$ & 2.51 & $0.020^{*}$ & 5.66 & $0.000 *$ \\
\hline P x Sta x Lrs & 8 & 13.65 & $0.000 *$ & 4.69 & $0.000 *$ & 6.65 & $0.000^{*}$ & 5.15 & $0.000 *$ \\
\hline \multicolumn{10}{|l|}{ Nematoda } \\
\hline Periods (P) & 1 & 88.53 & $0.000^{*}$ & 57.19 & $0.000 *$ & 5.99 & $0.017^{*}$ & 74.31 & $0.000 *$ \\
\hline Stations (Sta) & 4 & 29.12 & $0.000 *$ & 32.07 & $0.000 *$ & 2.57 & $0.046^{*}$ & 36.31 & $0.000 *$ \\
\hline Layers (Lrs) & 2 & 16.68 & $0.000^{*}$ & 5.45 & $0.006^{*}$ & 3.90 & $0.025^{*}$ & 7.18 & $0.001 *$ \\
\hline P x Sta & 4 & 3.07 & $0.022 *$ & 2.38 & 0.061 & 2.33 & 0.065 & 7.25 & $0.000^{*}$ \\
\hline P x Lrs & 2 & 15.19 & $0.000^{*}$ & 6.99 & $0.001 *$ & 3.80 & $0.027^{*}$ & 11.55 & $0.000 *$ \\
\hline Sta $x$ Lrs & 8 & 6.81 & $0.000^{*}$ & 4.89 & $0.000 *$ & 1.98 & 0.064 & 6.42 & $0.000^{*}$ \\
\hline P x Sta x Lrs & 8 & 2.62 & $0.015^{*}$ & 1.97 & 0.064 & 1.65 & 0.128 & 1.91 & 0.074 \\
\hline
\end{tabular}


Differently, in the dry period, density was lower at S1 (196.58 ind. $/ 10 \mathrm{~cm}^{2}$ ) and it followed an increasing trend towards the low tide mark, with higher density closer to the waterline (S5) (706.92 ind./10 $\left.\mathrm{cm}^{2}\right)$ (Figure 2A). Considering sediment layers, in the rainy period density was higher in the upper sediment layer (0-2cm) (635.99 to 4977.11 ind. $/ 10 \mathrm{~cm}^{2}$ ) and lower in the lower sediment layer $(5-10 \mathrm{~cm})\left(24.53\right.$ to $\left.474.75 \mathrm{ind} / 10 \mathrm{~cm}^{2}\right)$ at all stations (Figure 3A). In the intermediate sediment layer $(2-5 \mathrm{~cm})$ the density varied from 131.16 to 1184.71 ind. $/ 10 \mathrm{~cm}^{2}$. In the dry period the highest density was observed in different sediment layers depending on the station: higher in $5-10 \mathrm{~cm}$ at $\mathrm{S} 1$ and $\mathrm{S} 2\left(228.25\right.$ and 796.41 ind. $/ 10 \mathrm{~cm}^{2}$, respectively), higher in $0-2 \mathrm{~cm}$ at $\mathrm{S} 3$ and $\mathrm{S} 4$ (897.85 and 1411.65 ind. $/ 10 \mathrm{~cm}^{2}$, respectively), and in S5 the highest density was found in $2-5 \mathrm{~cm}\left(842.17\right.$ ind.$\left./ 10 \mathrm{~cm}^{2}\right)$ (Figure 3B). Differences in density were significant among stations and sediment layers for S1 and S3 (rainy period) and S4 and S5 (dry period), with the highest densities occurring in $0-2 \mathrm{~cm}$.

The number of taxa was similar among the intertidal stations, while the richness was higher in $0-2 \mathrm{~cm}$ at most stations, especially in the rainy period (Figures $3 \mathrm{~A}$ and $3 \mathrm{~B}$ ).

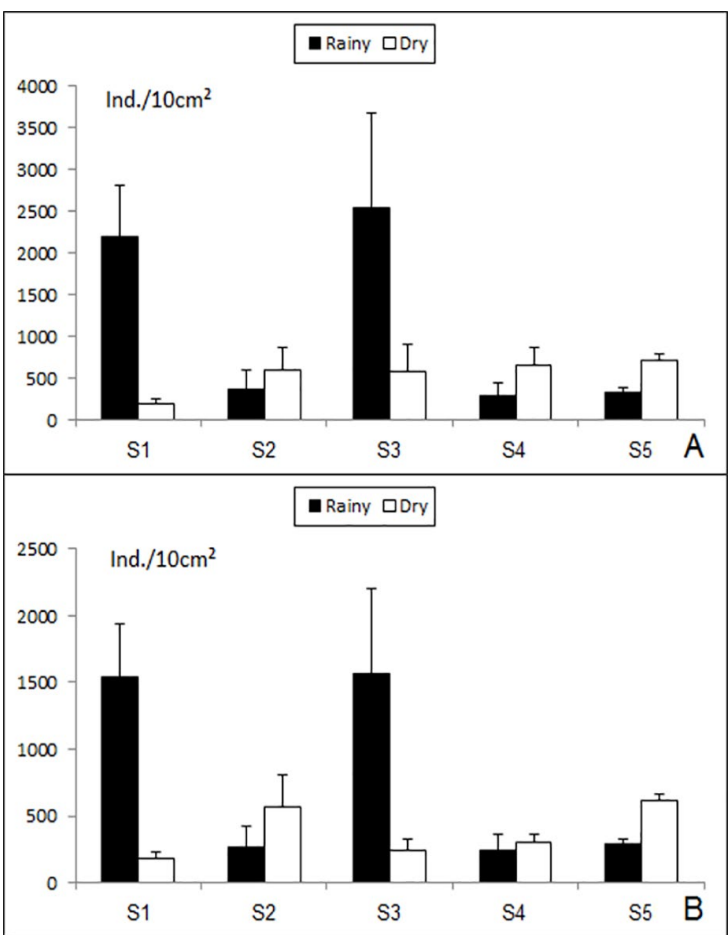

Figure 2. Mean density (ind. $/ 10 \mathrm{~cm}^{2} \pm$ standard deviations) of meiofauna (A) and Nematoda (B) at Caixa d'Água beach stations during the rainy and dry periods.

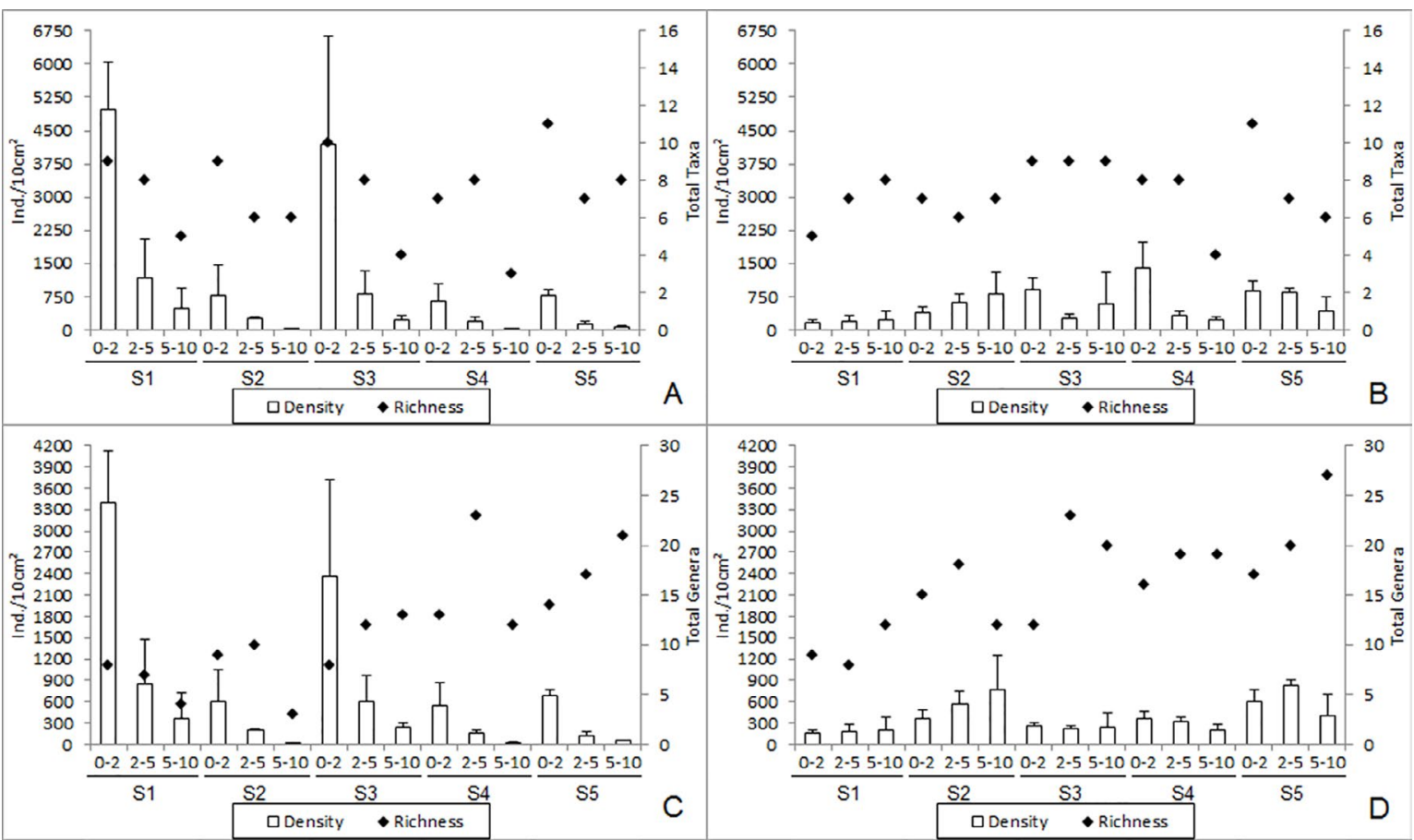

Figure 3. Mean density (ind./10 $\mathrm{cm}^{2} \pm$ standard deviations) and richness of meiofauna [rainy (A) and dry (B) periods] and Nematoda [rainy (C) and dry (D) periods] in sediment layers at beach stations at Caixa d'Água beach. 
Group richness varied in both dry and rainy periods, as follow: rainy period - from 7 at $\mathrm{S} 4$ to 11 at $\mathrm{S} 5(0-2 \mathrm{~cm})$, from 6 at $\mathrm{S} 2$ to 8 at $\mathrm{S} 1(2-5 \mathrm{~cm})$ and from 3 at $\mathrm{S} 4$ to 8 at $\mathrm{S} 5$ $(5-10 \mathrm{~cm})$; dry period - from 5 at $\mathrm{S} 1$ to 11 at $\mathrm{S} 5(0-2 \mathrm{~cm})$, 6 at S2 to 8 at $\mathrm{S} 4(2-5 \mathrm{~cm})$ and from 4 at $\mathrm{S} 4$ to 9 at S3 $(5-10 \mathrm{~cm})$ (Figures $3 \mathrm{~A}$ and $3 \mathrm{~B})$. The high richness found in $0-2 \mathrm{~cm}$ of S5 (dry period) accounted for differences in richness. The low diversity found at S3 and S4 in $5-10 \mathrm{~cm}$ (rainy period) accounted for differences in diversity. On the other hand, the low species evenness found in the $5-10 \mathrm{~cm}$ at S3 (dry period) accounted for differences in evenness.

In the rainy period, Nematoda was the dominant taxon in all sediment layers at all sampling stations (maximum of $3398.91 \mathrm{ind} . / 10 \mathrm{~cm}^{2}$ in $0-2 \mathrm{~cm}$ of S1) (Figure $4 \mathrm{~A}$ ), except for $5-10 \mathrm{~cm}$ of $\mathrm{S} 2$, where Rotifera had the highest density (17.92 ind./10 $\mathrm{cm}^{2}$ ) (Figure 4B). During dry period, Nematoda also dominated all sediment layers (maximum of 826.13 ind./10 $\mathrm{cm}^{2}$ in $2-5 \mathrm{~cm}$ of S5) (Figure $4 \mathrm{~A}$ ), except for the $0-2 \mathrm{~cm}$ of $\mathrm{S} 3$ and $\mathrm{S} 4$, and $5-10 \mathrm{~cm}$ of $\mathrm{S} 3$, where Tardigrada was dominant with $442.08,897.95$, and 294.40 ind. $/ 10 \mathrm{~cm}^{2}$, respectively (Figure $4 \mathrm{C}$ ).
Regarding meiofaunal community structure, PERMANOVA showed significant differences between periods, stations and sediment layers (Table 2). Considering stations, significant differences were not found only between S1 and S3 during rainy period (Table 3). Differences between periods, stations, and sediment layers can be seen in the non-metric multidimensional ordination (nMDS) figures (Figure 5). Regarding periods, although the nMDS analysis showed some mixture between samples, it still indicated differences between the rainy and the dry periods (Figure 5A). Regarding the horizontal structure, the nMDS analysis did not show a clear clustering among stations (Figure 5B). On the other hand, and regarding the vertical structure, although the nMDS analysis showed some mixture it still indicated difference between sediment layers (Figure 5C).

SIMPER analysis showed that the mean dissimilarity between periods was $48.87 \%$. Tardigrada (17.40\%), Turbellaria (17.07\%), and Rotifera (16.76\%) were the groups that contributed most to dissimilarity between periods.
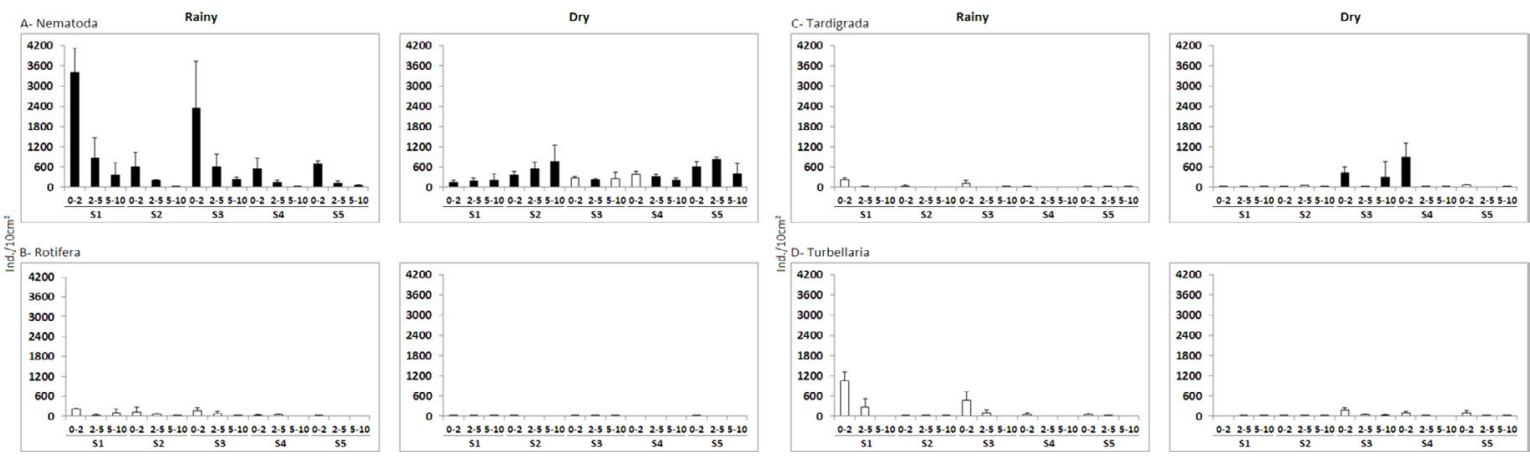

Figure 4. Mean density (ind. $/ 10 \mathrm{~cm}^{2} \pm$ standard deviations) of the most abundant meiofaunal groups in sediment layers at Caixa d'Água beach stations during the rainy and dry period. The black bars indicate the highest density found among the groups in the corresponding sediment layer and station.

Table 2. Results of PERMANOVA tests for comparing the multivariate structure of meiofauna community and Nematoda associations among periods, stations and sediment layers at Caixa d'Água beach. Asterisks represent significant differences $(p<0.05)$.

\begin{tabular}{|c|c|c|c|c|c|c|c|}
\hline \multirow[b]{2}{*}{ Factors } & \multicolumn{4}{|c|}{ Meiofauna } & \multicolumn{3}{|c|}{ Nematoda } \\
\hline & df & MS & Pseudo-F & $p($ perm $)$ & MS & Pseudo-F & $p($ perm $)$ \\
\hline Periods (P) & 1 & 9264 & 30.153 & $0.001 *$ & 24745 & 28.774 & $0.001 *$ \\
\hline Stations (Sta) & 4 & 2159.6 & 7.0291 & $0.001 *$ & 13088 & 15.219 & $0.001 *$ \\
\hline Layers (Lrs) & 2 & 9782.1 & 31.839 & $0.001 *$ & 15480 & 18 & $0.001 *$ \\
\hline P x Sta & 4 & 2889.1 & 9.4036 & $0.001 *$ & 5966.8 & 6.9382 & $0.001 *$ \\
\hline P x Lrs & 2 & 2199.5 & 7.1592 & $0.001 *$ & 4974.9 & 5.7848 & $0.001 *$ \\
\hline Sta $x$ Lrs & 8 & 1109.4 & 3.611 & $0.001 *$ & 2931.1 & 3.4083 & $0.001 *$ \\
\hline P x Sta x Lrs & 8 & 1417.6 & 4.6142 & $0.001 *$ & 3117.6 & 3.6252 & $0.001 *$ \\
\hline Residue & 60 & 307.23 & & & 859.99 & & \\
\hline Total & 89 & & & & & & \\
\hline
\end{tabular}


Table 3. Results of the paired tests for the structure of meiofauna community and Nematoda associations between stations and sediment layers in each period at Caixa d'Água beach. Asterisks represent significant differences $(p<0.05)$.

\begin{tabular}{|c|c|c|c|c|}
\hline \multirow[b]{2}{*}{ Factors } & \multicolumn{2}{|c|}{ Meiofauna } & \multicolumn{2}{|c|}{ Nematoda } \\
\hline & $\mathrm{t}$ & $p($ perm $)$ & $\mathrm{T}$ & $p($ perm $)$ \\
\hline \multicolumn{5}{|l|}{ Rainy period } \\
\hline $\mathrm{S} 1 \times \mathrm{S} 2$ & 2.5785 & $0.003 *$ & 1.183 & 0.24 \\
\hline $\mathrm{S} 1 \times \mathrm{S} 3$ & 1.7167 & 0.078 & 2.5671 & $0.001 *$ \\
\hline $\mathrm{S} 1 \times \mathrm{S} 4$ & 3.461 & $0.001 *$ & 3.8818 & $0.001 *$ \\
\hline S1 x S5 & 3.9167 & $0.001 *$ & 2.9796 & $0.001 *$ \\
\hline $\mathrm{S} 2 \times \mathrm{S} 3$ & 3.3972 & $0.001 *$ & 1.5817 & $0.005^{*}$ \\
\hline $\mathrm{S} 2 \times \mathrm{S} 4$ & 2.2274 & $0.004 *$ & 2.4126 & $0.002 *$ \\
\hline S2 x S5 & 3.7805 & $0.001 *$ & 1.9321 & $0.004 *$ \\
\hline $\mathrm{S} 3 \times \mathrm{S} 4$ & 3.4706 & $0.001 *$ & 2.3681 & $0.001^{*}$ \\
\hline S3 x S5 & 3.4102 & $0.001 *$ & 1.9652 & $0.004 *$ \\
\hline S4 x S5 & 2.6127 & $0.002 *$ & 2.0233 & $0.001 *$ \\
\hline $0-2 \mathrm{~cm} \times 2-5 \mathrm{~cm}$ & 4.2612 & $0.001 *$ & 4.7948 & $0.001 *$ \\
\hline $0-2 \mathrm{~cm} \times 5-10 \mathrm{~cm}$ & 6.4355 & $0.001 *$ & 3.8828 & $0.001 *$ \\
\hline $2-5 \mathrm{~cm} \times 5-10 \mathrm{~cm}$ & 4.0018 & $0.001 *$ & 3.0761 & $0.001 *$ \\
\hline \multicolumn{5}{|l|}{ Dry period } \\
\hline $\mathrm{S} 1 \times \mathrm{S} 2$ & 2.2107 & $0,005^{*}$ & 3.1438 & $0.001 *$ \\
\hline $\mathrm{S} 1 \times \mathrm{S} 3$ & 3.0574 & $0.001 *$ & 5.1233 & $0.001 *$ \\
\hline $\mathrm{S} 1 \times \mathrm{S} 4$ & 2.3343 & $0.002 *$ & 6.716 & $0.001 *$ \\
\hline S1 x S5 & 2.8762 & $0.001 *$ & 5.447 & $0.001 *$ \\
\hline $\mathrm{S} 2 \times \mathrm{S} 3$ & 2.6753 & $0.001 *$ & 4.8343 & $0.001^{*}$ \\
\hline $\mathrm{S} 2 \times \mathrm{S} 4$ & 2.3003 & $0.002 *$ & 6.3943 & $0.001 *$ \\
\hline S2 x S5 & 2.4896 & $0.002 *$ & 5.2795 & $0.001 *$ \\
\hline $\mathrm{S} 3 \times \mathrm{S} 4$ & 1.7475 & $0.028^{*}$ & 3.0578 & $0.002 *$ \\
\hline S3 x S5 & 2.3748 & $0.001 *$ & 2.5074 & $0.001 *$ \\
\hline S4 x S5 & 1.9009 & $0.006^{*}$ & 2.0803 & $0.003 *$ \\
\hline $0-2 \mathrm{~cm} \times 2-5 \mathrm{~cm}$ & 3.9882 & $0.001 *$ & 3.2177 & $0.001 *$ \\
\hline $0-2 \mathrm{~cm} \times 5-10 \mathrm{~cm}$ & 3.8913 & $0.001 *$ & 3.5347 & $0.001 *$ \\
\hline $2-5 \mathrm{~cm} \times 5-10 \mathrm{~cm}$ & 2.3491 & $0.002 *$ & 2.3685 & $0.001 *$ \\
\hline
\end{tabular}

Regarding stations, SIMPER analysis showed that the highest dissimilarity within the community was between S1 and S5 (47.87\%). Again Tardigrada (17.95\%), Turbellaria (14.48\%), and Rotifera (14.41\%) were the groups that contributed most to dissimilarity. Regarding sediment layers, SIMPER analysis showed that the highest dissimilarity was between $0-2$ and $5-10 \mathrm{~cm}(54.60 \%)$. The same groups, Tardigrada (19.71\%), Turbellaria (18.60\%), and Rotifera (13.17\%), also contributed most to dissimilarity among sediment layers.

\section{NEMATODA}

Nematoda association was comprised of 2 classes, 7 orders, 28 families, and 72 genera (Table 4). Chromadoridae, Cyatholaimidae, Desmodoridae, and Xyalidae were the richest families, with 7 genera each. Dry period was richer (with 60 genera) than rainy period (with 48 genera). Of the genera found, 12 were exclusive to rainy period and 24 were exclusive to dry period.

Density, richness, diversity, and evenness significantly varied between periods, stations, and sediment layers (Table 1). 


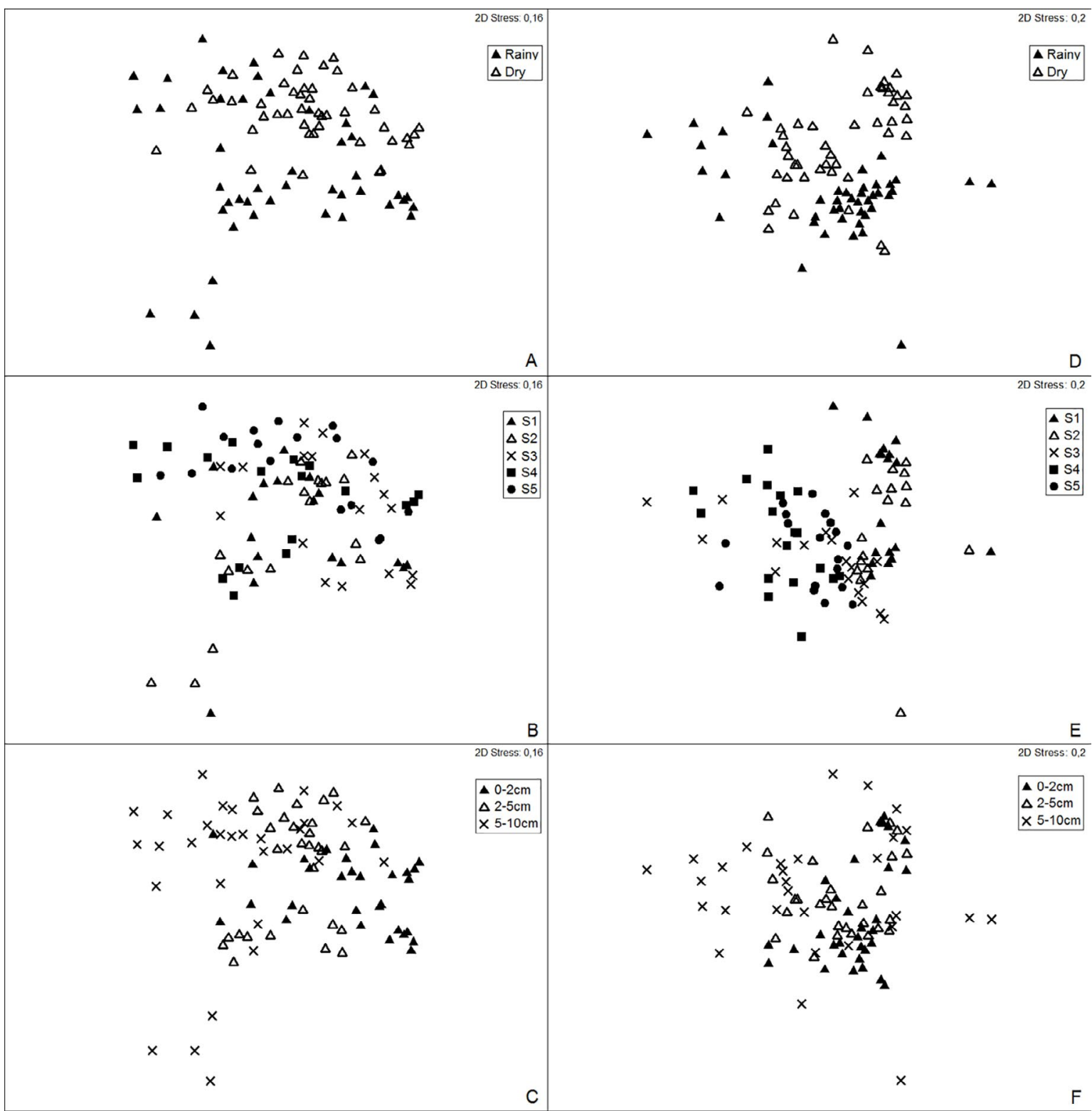

Figure 5. nMDS for meiofauna community [periods (A), stations (B) and sediment layers (C)] and Nematoda associations [periods (D), stations (E) and sediment layers (F)] at Caixa d'Água beach.

Significant variation in density, richness, diversity and eveness were also found considering interactions of the factors with few exceptions. Nematoda densities in the rainy period were higher at the central station (S3) $\left(1566.87\right.$ ind. $\left./ 10 \mathrm{~cm}^{2}\right)$ and at the station closer to the high tide mark (S1). On the other hand, in the dry period, similar to meiofauna, density was lower at S1 $\left(182.27\right.$ ind.$\left./ 10 \mathrm{~cm}^{2}\right)$ and it followed an increasing trend towards the low tide mark, with higher density at S5 $\left(613.03\right.$ ind.$\left./ 10 \mathrm{~cm}^{2}\right)$ (Figure 2B). Considering sediment layers, in the rainy period density was higher in $0-2 \mathrm{~cm}$
(553.90 ind. $/ 10 \mathrm{~cm}^{2}$ to 3398.91 ind. $/ 10 \mathrm{~cm}^{2}$ ) and lower in $5-10 \mathrm{~cm}\left(207.59\right.$ to 769.04 ind. $\left./ 10 \mathrm{~cm}^{2}\right)$ at all stations (Figure $3 \mathrm{C})$. In $2-5 \mathrm{~cm}$ the density varied from 122.67 to 858.69 ind. $/ 10 \mathrm{~cm}^{2}$. In the dry period the highest density was observed in different sediment layers depending on the station: higher in $5-10 \mathrm{~cm}$ at $\mathrm{S} 1$ and $\mathrm{S} 2\left(208.06\right.$ and 769.04 ind. $/ 10 \mathrm{~cm}^{2}$, respectively), higher in $0-2 \mathrm{~cm}$ at S3 and S4 (272.23 and $369.89 \mathrm{ind} . / 10 \mathrm{~cm}^{2}$, respectively), and in $\mathrm{S} 5$ the highest density was found in $2-5 \mathrm{~cm}\left(826.13\right.$ ind./10 $\left.\mathrm{cm}^{2}\right)$ (Figure 3D). The significant differences in density between periods were due to the fact that the rainy period had the highest densities. 
Table 4. List of Nematoda taxa recorded during the rainy (R) and dry (D) periods, stations (S1, S2, S3, S4, S5) and sediment layers (0-2, 2-5 e 5-10) at Caixa d'Água beach.

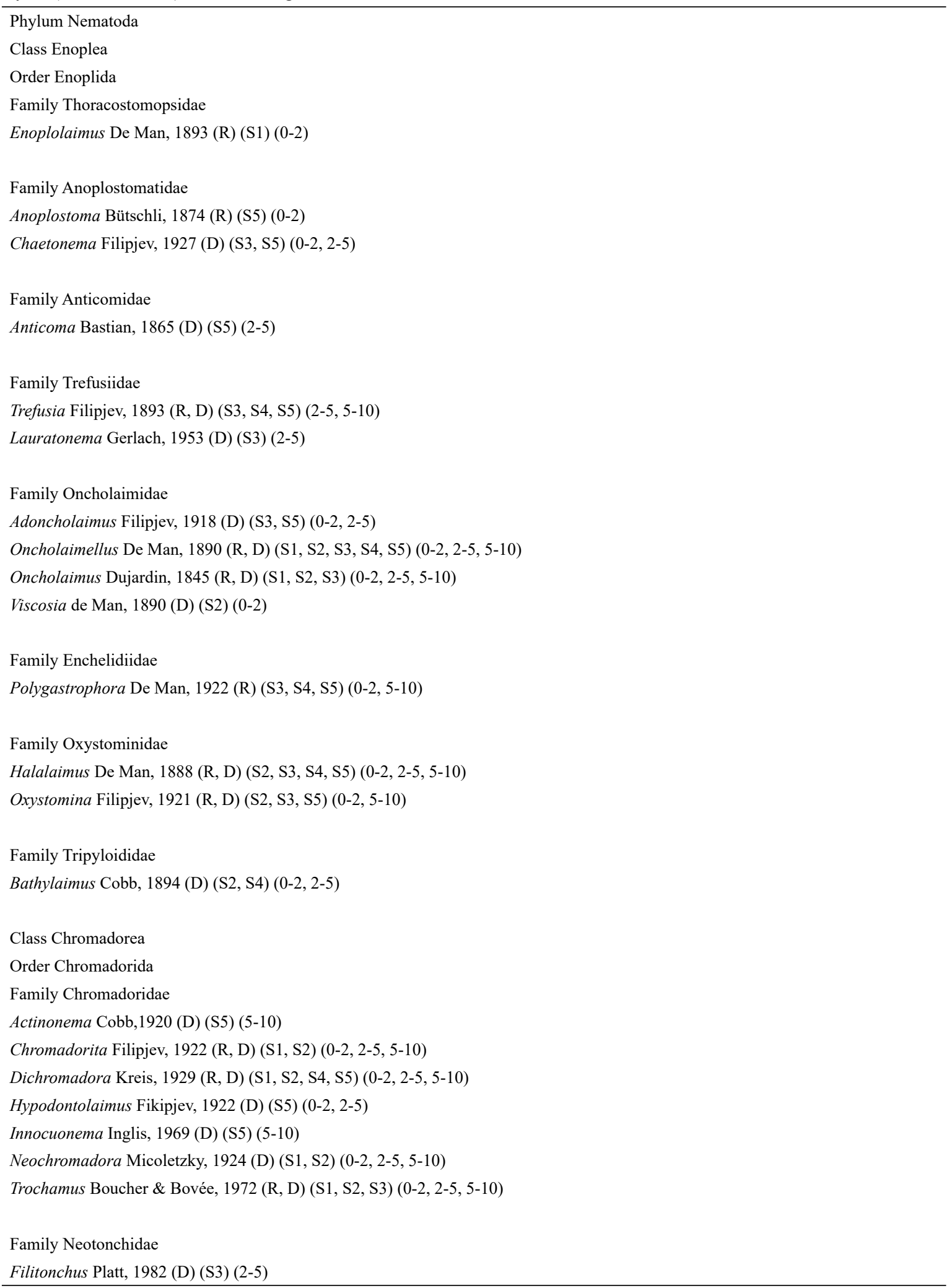


Continued Table 4.

Gomphionema Wieser \& Hopper, 1966 (R) (S3, S4, S5) (0-2, 2-5, 5-10)

Nannolaimus Cobb, 1920 (R) (S4, S5) (2-5, 5-10)

Neotonchus Cobb, 1933 (R, D) (S3, S4, S5) (5-10)

Family Cyatholaimidae

Longicyatholaimus Micoletzk, 1924 (R, D) (S2, S3, S4, S5) (2-5, 5-10)

Marylynnia Hopper, 1977 (D) (S2) (0-2)

Metacyatholaimus Stekhoven, 1942 (R) (S4) (2-5)

Nannolaimoides Ott, 1972 (R, D) (S4, S5) (2-5)

Paralongicyatholaimus Stekhoven, 1942 (R, D) (S3, S4, S5) (2-5, 5-10)

Pomponema Cobb, 1917 (R, D) (S3, S4, S5) (2-5, 5-10)

Praeacanthonchus Micoletzky, 1924 (R) (S2) (5-10)

Family Selachinematidae

Choniolaimus Ditlevsen, 1918 (R) (S3, S5) (2-5)

Gammanema Cobb, 1920 (R, D) (S1, S2, S3, S4, S5) (2-5, 5-10)

Order Desmodorida

Family Desmodoridae

Catanema Cobb, 1920 (R, D) (S3, S4, S5) (5-10)

Chromaspirinia Filipjev, 1918 (R, D) (S1, S2, S3, S4, S5) (0-2, 2-5, 5-10)

Eubostrichus Greef, 1869 (R, D) (S5) (5-10)

Metachromadora Filipjev, 1918 (D) (S3) (2-5)

Molgolaimus Ditlevisen, 1921 (R, D) (S3, S5) (5-10)

Pseudochromadora Daday, 1889 (R, D) (S3) (0-2, 2-5, 5-10)

Spirinia Gerlach, 1963 (R, D) (S1, S2, S3, S4, S5) (0-2, 2-5, 5-10)

Family Draconematidae

Paradraconema Allen \& Noffsinger, 1978 (R, D) (S2) (2-5)

Family Microlaimidae

Microlaimus De Man, 1880 (R, D) (S1, S2, S3, S4, S5) (0-2, 2-5, 5-10)

Spirobolbolaimus Soeatert \& Vincx, 1988 (R, D) (S4, S5) (2-5)

Family Monoposthidae

Monoposthia De Man, 1989 (D) (S3) (2-5)

Nudora Cobb, 1920 (R, D) (S2, S3, S4, S5) (0-2, 2-5, 5-10)

Order Desmoscolecida

Family Desmoscolecidae

Desmoscolex Claparède, 1863 (D) (S2) (2-5)

Family Cyartonematidae

Cyartonema Cobb,1920 (D) (S4) (5-10)

Order Monhysterida

Family Sphaerolaimidae 
Continued Table 4.

Sphaerolaimus Bastian, 1865 (D) (S1) (5-10)

Family Xyalidae

Ammotheristus Lorenzen, 1977 (R) (S4, S5) (2-5)

Daptonema Cobb, 1920 (R, D) (S1, S2, S3, S4, S5) (0-2, 2-5, 5-10)

Omicronema Cobb, 1920 (R, D) (S2, S4, S5) (0-2, 2-5, 5-10)

Paramonohystera Steiner, 1916 (R) (S4) (2-5)

Prorhynchonema Gourbault, 1982 (R, D) (S1, S2, S3, S4, S5) (0-2, 2-5, 5-10)

Theristus Bastian, 1865 (R, D) (S1, S2, S3, S4, S5) (0-2, 2-5, 5-10)

Trichotheristus Wieser, 1956 (D) (S1, S2, S3, S4, S5) (0-2, 2-5, 5-10)

Family Linhomoeidae

Eumorpholaimus Schulz, 1932 (R) (S5) (0-2)

Linhomoeus Bastian, 1865 (R, D) (S3, S4, S5) (0-2, 2-5, 5-10)

Metalinhomoeus De Man, 1907 (D) (S3, S4, S5) (5-10)

Terschellingia De Man, 1888 (R, D) (S1, S3, S4, S5) (0-2, 2-5, 5-10)

Order Araeolaimida

Family Axonolaimidae

Axonolaimus De Man, 1889 (R, D) (S1, S2, S3, S4, S5) (0-2, 2-5, 5-10)

Odontophora Bütschli, 1874 (R, D) (S3, S4, S5) (0-2, 2-5, 5-10)

Family Comesomatidae

Paracomesoma Hope \& Murphy, 1972 (D) (S4) (2-5)

Sabatieria Rouville, 1903 (R, D) (S3, S4, S5) (0-2, 5-10)

Family Diplopeltidae

Campylaimus Cobb, 1920 (R) (S5) (2-5)

Order Plectida

Family Leptolaimidae

Dagda Southern, 1924 (D) (S4) (0-2)

Leptolaimus De Man, 1876 (D) (S4) (0-2)

Family Aegialoalaimidae

Aegialoalaimus De Man, 1907 (R, D) (S2, S3, S4, S5) (0-2, 2-5)

Family Diplopeltoididae

Diplopeltoides Gerlach, 1962 (R, D) (S4, S5) (0-2, 2-5, 5-10)

Family Ceramonematidae

Dasynemoides Chitwood, 1936 (R, D) (S2, S3, S4, S5) (0-2, 2-5, 5-10)

Metadasynemoides Haspeslagh, 1973 (R, D) (S3, S4, S5) (0-2, 2-5)

Pselionema Cobb, 1933 (D) (S5) (2-5) 
Low densities found in $5-10 \mathrm{~cm}$ of $\mathrm{S} 2$ and in $2-5 \mathrm{~cm}$ of S4 (rainy period) were responsible for the differences in densities among stations and sediment layers.

Nematofauna richness had an increasing trend towards the low tide mark, and it had lower richness in $0-2 \mathrm{~cm}$ at most stations. This richness varied in both dry and rainy periods, as follow: rainy period - from 8 at S1 and S3 to 14 at $\mathrm{S} 5(0-2 \mathrm{~cm})$, from 7 at $\mathrm{S} 1$ to 17 at $\mathrm{S} 5(2-5 \mathrm{~cm})$ and from 3 at $\mathrm{S} 2$ to 21 at $\mathrm{S} 5(5-10 \mathrm{~cm})$; dry period - from 9 at $\mathrm{S} 1$ to 17 at $\mathrm{S} 5(0-2 \mathrm{~cm})$, from 8 at $\mathrm{S} 1$ to 23 at S4 $(2-5 \mathrm{~cm})$ and from 12 at $\mathrm{S} 1$ and $\mathrm{S} 2$ to 27 at $\mathrm{S} 5(5-10 \mathrm{~cm})$ (Figures $3 \mathrm{C}$ and $3 \mathrm{D})$. The high richness found in $2-5 \mathrm{~cm}$ of $\mathrm{S} 4$ (rainy period) accounted for differences in richness. The low diversity found in $5-10 \mathrm{~cm}$ of S1 and S2 (rainy period) accounted for differences in diversity. On the other hand, the low species evenness found in $5-10 \mathrm{~cm}$ of S1 and S2 (rainy period) accounted for differences in evenness between periods, stations, and sediment layers.

Daptonema was present in all sediment layers of almost all stations in the rainy period, and it had the highest density at most stations (maximum of 41.99 ind. $/ 10 \mathrm{~cm}^{2}$ in $2-5 \mathrm{~cm}$ of S3) (Figure 6A). Where Daptonema did not have the highest density, Theristus (Figure 6B), Axonolaimus (Figure 6C), Odontophora (Figure 6D), and Oncholaimellus (Figure 6E) were the dominant genera. On the other hand, in the dry period Theristus was present in all sediment layers of almost all stations, with the highest density at most stations (maximum of 30.19 ind. $/ 10 \mathrm{~cm}^{2}$ in $0-2 \mathrm{~cm}$ of $\mathrm{S} 1$ ) (Figure $6 \mathrm{~B}$ ). Where Theristus did not have the highest density, the dominant genera were Chromaspirinia (Figure 6F), Trochamus (Figure 6G), Adoncholaimus (Figure 6H), Daptonema (Figure 6A), Oncholaimellus (Figure 6E), and Odontophora (Figure 6D).

Considering trophic groups, non-selective deposit-feeders (1B) dominated nearly all sediment layers of all stations during rainy period, ranging from $5 \%$ in $5-10 \mathrm{~cm}$ of $\mathrm{S} 3$ to $98 \%$ in $5-10 \mathrm{~cm}$ of S1 (Figure $7 \mathrm{~A}$ ). In the dry period, however, there was decrease in non-selective deposit-feeders, and therefore, increase in other trophic groups, such as epistrate feeders (2A) (Figure 7B). Hence, there was an alternation of dominance between non-selective deposit-feeders (1B) and epistrate feeders (2A) in the dry period. On the other hand, the abundance of predators (2B) and selective deposit-feeders (1A) increased at S3, S4, and S5 of the intertidal zone in both periods (Figures 7A and B).
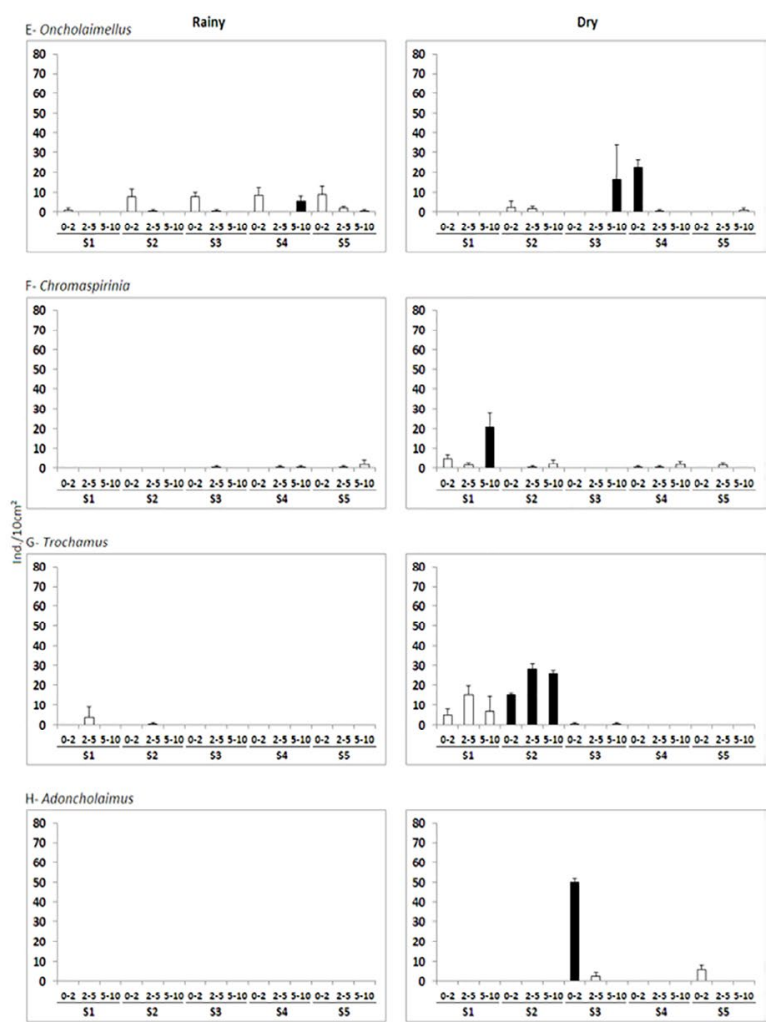

Figure 6. Mean density (ind. $/ 10 \mathrm{~cm}^{2} \pm$ standard deviations) of the most abundant Nematoda genera in sediment layers at Caixa d'Água beach stations during the rainy and dry period. The black bars indicate the highest density found among the genera in the corresponding sediment layer and station. 


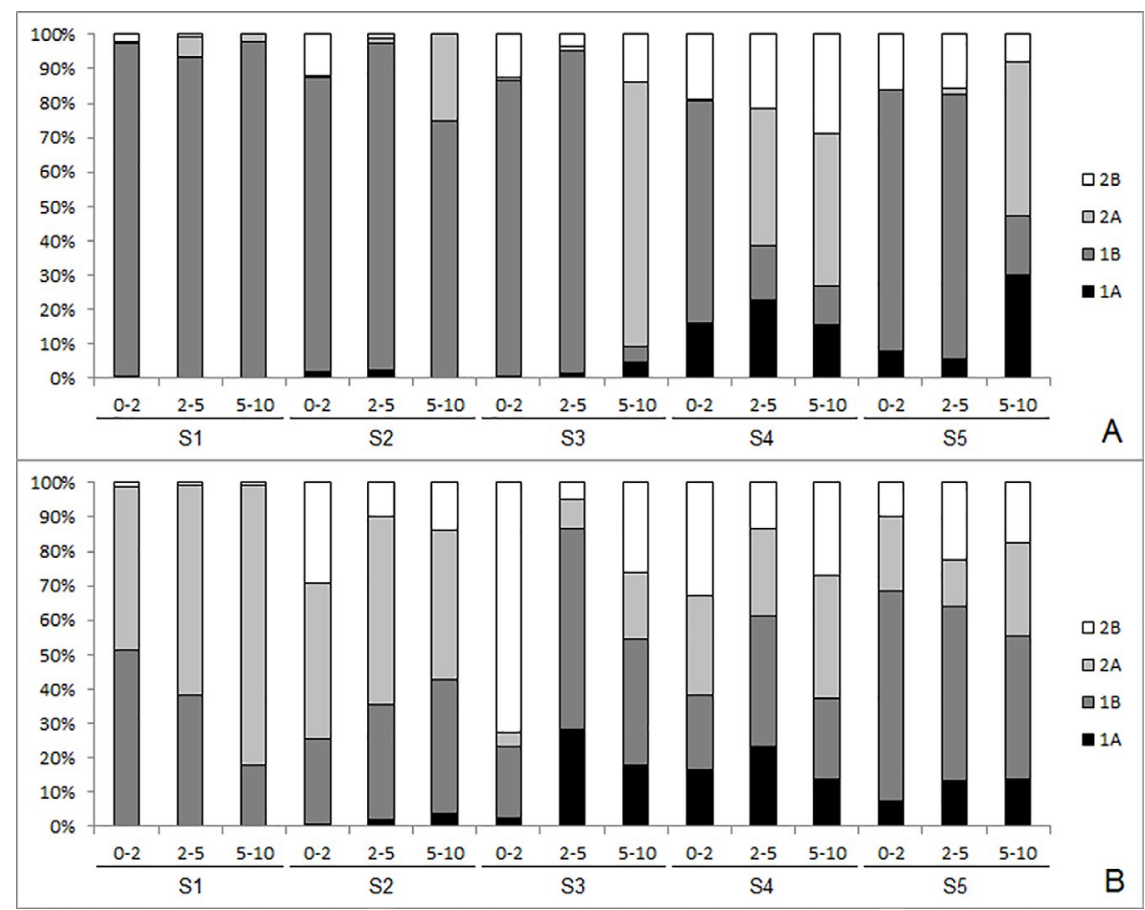

Figure 7. Relative abundance (\%) of the Nematoda feeding types in sediment layers at Caixa d'Água beach stations during the rainy $(\mathrm{A})$ and dry $(\mathrm{B})$ period $(1 \mathrm{~A}=$ selective deposit feeders, $1 \mathrm{~B}=$ non-selective deposit feeders, $2 \mathrm{~A}=$ epistrate feeders, $2 \mathrm{~B}=$ predators/omnivores).

Regarding Nematoda association structure, PERMANOVA showed significant differences between periods, stations (except between $\mathrm{S} 1$ and $\mathrm{S} 2$ in the rainy period), and sediment layers (Tables 2 and 3). Differences between periods, stations, and sediment layers might be seen in the non-metric multidimensional ordination (nMDS) plots (Figure 5). Regarding periods, although the nMDS analysis showed some mixture, it still indicated difference between them (Figure 5D). Regarding the horizontal structure, the nMDS analysis grouped nematofauna from Caixa d'Água beach into two associations. The first one was comprised of the samples from S1 and $\mathrm{S} 2$, and the second association was comprised of samples from the other three stations (S3, S4, and S5) (Figure 5E). Regarding vertical structure, the nMDS analysis showed that $5-10 \mathrm{~cm}$ is the most differentiated, as it is not as clustered with the other two, more superficial sediment layers (0-2 and $2-5 \mathrm{~cm})$ (Figure 5F).

SIMPER analysis showed that the mean dissimilarity between periods was $75.68 \%$. Daptonema $(8.24 \%)$, Theristus (6.72\%), and Axonolaimus (5.74\%) were the genera that contributed most to dissimilarity between periods. Regarding stations, SIMPER analysis showed that the highest dissimilarity was between S1 and S4
(75.68\%). Daptonema (8.24\%), Theristus (6.72\%), and Dasynemoides $(6.31 \%)$ were the genera that contributed most to dissimilarity among stations. Regarding sediment layers, SIMPER analysis showed that the highest dissimilarity was between $0-2$ and $5-10 \mathrm{~cm}$ (79.05\%). Daptonema (9.97\%), Axonolaimus (7.76\%), and Theristus $(7.21 \%)$ were the genera that contributed most to dissimilarity among sediment layers.

\section{DISCUSSION}

The dominance of Nematoda in the meiofauna community has been widely described in literature by several authors. This taxon generally dominates meiofauna, accounting for over $50 \%$ of the total number of individuals (Coull, 1988), and it might reach up to $90 \%$ of the total fauna in habitats with medium-to-fine sand grain (Giere, 2009). In Caixa d'Água beach very fine sand dominates the sediment (Rosa-Filho et al., 2011), fact that can explain the dominance of Nematoda.

Meiofauna densities found on Caixa d'Água (mean total density of $547.51 \mathrm{ind} . / 10 \mathrm{~cm}^{2}$ in the rainy period and 1144.83 ind. $/ 10 \mathrm{~cm}^{2}$ in the dry period) were considerably lower than those found in other studies. Albuquerque et 
al. (2007) recorded values from 1556 to 13125 ind./10 $\mathrm{cm}^{2}$ on Restinga da Marambaia beach (Rio de Janeiro-Brazil). However, this type of comparison must be done with caution, as sampling effort and corer size vary among the studies on meiofauna. This fact could explain the higher densities found by Albuquerque et al. (2007), who used a corer with $3.5 \mathrm{~cm}$ diameter and $30 \mathrm{~cm}$ long. Furthermore, Restinga da Marambaia has only marine influence, while Caixa d'Água is influenced by Marapanim river, fact that probably also have an influence in the density. When compared with studies conducted in the Amazon region, where the size of the corer and the influence of rivers were similar, Caixa d'Água had values similar to those found by Rosa-Filho et al. (2011) (500 - 4000 ind./10 $\left.\mathrm{cm}^{2}\right)$ and Ataide et al. (2014) (1710 - 1832 ind./10 $\left.\mathrm{cm}^{2}\right)$, both conducted on the same beach or nearby. However, Caixa d'Água, which is an intermediate beach, had considerably higher density than Ajuruteua beach (also in the Amazon region and considered a dissipative beach), studied by Gomes and Rosa-Filho (2009), who found densities ranging from 553 to 674 ind. $/ 10 \mathrm{~cm}^{2}$. Studying meiofauna of sandy beaches, McLachlan \& Turner (1994) concluded that intermediate beaches provide suitable conditions for the success of interstitial fauna, which has higher densities and diversity. This fact occurs because these environments do not have extreme physical and chemical factors governing fauna, which might explain the higher densities found on Caixa d'Água.

Horizontally, meiofauna is generally more abundant in the mid-tidal level (Giere, 2009). On Caixa D’Água beach, meiofauna density, as well as nematofauna density, was also higher at the central station (S3) of the intertidal zone in the rainy period, thus corroborating the pattern mentioned above. This higher faunal density in the mid-tidal level of the beach was also found by Armonies and Reise (2000) on a beach located in Sylt Island, North Sea, by Kotwick et al. (2005) on Heist beach, Belgium, and by Gingold et al. (2010) on a beach of the Gulf of California, Mexico, all of which are macrotidal beaches. However, on Caixa d'Água beach, the station closer to the high tide mark (S1) also had a high meiofauna density. This pattern of high density close to the high tide mark has already been recorded by Rodríguez et al. (2001) in Chile. Differently, in the dry period density was lower on Caixa d'Água beach in the high intertidal zone (S1) and it followed an increasing trend towards the low tide mark, with higher density at the station closer to the waterline (S5). Similar results were observed by Gheskiere et al. (2002) and Gheskiere et al. (2004), who studied the macrotidal beach De Panne in Belgium. Therefore, on Caixa d'Água beach, the middle intertidal zone seems to be the most stable region of the beach in the rainy period whereas the low intertidal zone seems to be the most favorable site for fauna in the dry period.

McLachlan (1983) and McLachlan and Turner (1994) consider the middle intertidal zone as the most suitable to the existence of dense meiofauna populations, as it has the most favorable conditions for interstitial organisms regarding balance between water content, oxygen input, and physical stability. In the rainy period, fauna followed the general pattern suggested above; however, in the dry period, fauna seemed to be responding more sharply to the fluctuation in sediment moisture, with preference for dominating the low tide mark. This pattern is probably due to the sharp decrease in the precipitation and increase in temperature that occur in the Amazon region during the driest months of the year. We suggest that in Amazon region meiofauna changes its colonization pattern on sandy beaches with the climatic period: higher densities at mid-tidal level on rainy period and higher densities at low tide mark on dry period. These patterns can be confirmed in future long-term studies.

The vertical distribution of meiofauna and nematofauna in the rainy period followed the pattern already mentioned by several authors at other locations (i.e. Coull and Bell, 1979), decreasing their density with increased sediment depth. In the dry period, however, meiofauna did not follow this pattern at all stations. Quite the opposite, at the two stations closer to the high tide mark (S1 and S2), fauna had similar densities among the sediment layers, with a tendency towards higher density in the lower sediment layer $(5-10 \mathrm{~cm})$ and lower density in the upper sediment layer $(0-2 \mathrm{~cm})$. The tendency towards lower density in the upper sediment layer at the two first stations, which are closer to the high tide mark in the dry period, is likely due to the fact that this part of the beach is the least moist during low tide, which discourages the presence of organisms, especially in the driest months of the year. According to Jansson (1968), water content in the sediment is one of the most important factors that influence meiofauna distribution (which includes Nematoda), as the organisms might migrate from upper portions of the sediment to the lower ones to avoid desiccation. Hence, the result obtained in this study confirms what has been suggested by McLachlan (1977); that meiofauna is present mostly under conditions where oxygen is abundant, a fact observed at all stations of the intertidal zone in the rainy period. Additionally, 
these organisms attempt to avoid desiccation (McLachlan, 1977) changing their sediment layer preference at stations which are farther from the waterline in the dry period, showing once again the impact of this period of the year on fauna distribution.

Regarding vertical taxon zonation, Nematoda were present in all sediment layers, with high abundance in nearly all sediment layers of all stations. Generally, Nematoda is a group with high tolerance to low amount of oxygen, while other taxa, such as Copepoda, are more sensitive to decreased oxygenation (Elmgren, 1975; Murrell and Fleeger, 1989; Modig and Ólafsson, 1998; Moodley et al., 2000; Kotwick et al., 2005). Turbellaria had a higher abundance pattern in the upper sediment layers of nearly all stations, which was also observed by Kotwick et al. (2005), who studied sandy beaches in a temperate region (Europe).

In tropical areas, seasonal changes are less defined compared to temperate areas, but most organisms of the meiofauna have some seasonality, with higher abundance in hotter months (Coull, 1988). This pattern was not observed on Caixa d'Água beach. Quite the opposite, meiofauna had higher mean density in the rainy period. A similar result was found by Pinto \& Santos (2006) on Coroa do Avião beach in northeastern Brazil and by other authors in different types of environments of tropical areas worldwide, e.g. estuaries along the western coast of India (Ansari and Parulekar, 1993), a mangrove in Australia (Alongi, 1987), and a mudflat in northeastern Australia (Dittman, 2000). However, in the present study, there were sharp changes in the representativity level of some groups in the different periods studied. Predominantly freshwater taxa such as Rotifera (Giere, 2009) tends to benefit from the rainy period, which is indicated by their increased density, and can be observed in the meiofauna community of Caixa d'Água in the rainy period. On the other hand, Tardigrada had higher density in the dry period, and this pattern was also found by Rocha et al. (2004) who recorded the highest Tardigrada density, more specifically of the species Batillipes pennaki, in the low intertidal zone during dry period in Itamaracá, northeastern Brazil.

The number of Nematoda genera recorded (72) lay within the values found on beaches worldwide, e.g. by Fonseca-Genevois et al. (2004), who found 62 genera in Cabo Frio, southeastern Brazil; Maria et al. (2008), who found 62 genera on beaches of the Guanabara Bay, also in southeastern Brazil; Gingold et al. (2010), who found 96 genera on El Tornillal beach in the Gulf of California, Mexico; Gheskiere et al. (2004) and Maria et al. (2013), who found, respectively, 65 and 60 genera on De Panne, Belgium. The three latter were also conducted on macrotidal beaches. However, the genus richness found in the present study was higher than the only study conducted on a Brazilian Amazon beach (Melo et al., 2013), where 47 genera were recorded. The highest sampling effort used in the present study might explain the higher genus richness found. Furthermore, $69 \%$ of the genera found are new records for Amazon beaches.

Horizontally, nematofauna richness increased towards the low tide mark, while vertically, a lower richness was recorded in the upper sediment layer in most stations. As the densities were higher in upper sediment layer, this means that few genera (in this case Daptonema and/or Theristus) dominated the association. This decreased richness in the upper sediment layer and towards the region closer to the high tide mark is probably a response of Nematodes to desiccation caused by the higher exposure that occurs at these sites during low tide. Only more tolerant genera to desiccation remained in these situations. This horizontal pattern did not corroborate other studies conducted on macrotidal beaches, where nematofauna had higher richness in the mid-tidal level of the beach (Armonies and Reise, 2000; Gheskiere et al., 2004; Gingold et al., 2010; Maria et al., 2013). Unlike the other macrotidal beaches mentioned above, Caixa d'Água beach is situated in the tropical region. This means it is under the influence of the high temperatures present in this region throughout the year. These high temperatures in the tropical region are considered to have higher importance in the structuring of nematofauna, which was evident in the nematofauna richness pattern across stations of the intertidal zone on the studied beach.

The dominance of detritivorous genera on Caixa d'Água beach is probably related to sediment grain size and to the likely high organic matter input in the region. Heip et al. (1985), who revised marine Nematoda ecology, mentioned the dominance of detritivorous genera, e.g. Daptonema and Theristus (both from the family Xyalidae), in environments with small-sized sediment grains. Additionally, several other studies have shown the dominance of the family Xyalidae in environments with fine-to-medium grains (Nicholas and Hodda, 1999; Gheskiere et al. 2004; Hourston et al. 2005; Moreno et al. 2006; Mundo-Ocampo et al. 2007). Deposit-feeding benthic organisms benefit from organic matter input derived from rivers (Montagna and Kalke, 1992; Snelgrove and Butman, 1994) and might therefore have high abundance, which is what probably 
happens on Caixa d'Água. The region where this beach is situated is directly affected by the waters of the Marapanim Bay and its estuary located west of Algodoal Island, which thus explains its high organic matter input.

Regarding seasonal variation, nematofauna had higher abundance, especially the 1B group (non-selective deposit-feeders), and lower richness during rainy period. The increase in abundance of Nematoda assemblages, particularly of non-selective deposit-feeders, and consequent decrease in Nematoda diversity might be a response to organic enrichment (Sandulli and De Nicola-Giudici, 1991; Coull and Chandler, 1992; Schratzberger and Warwick, 1998), which probably occurs on Caixa d'Água during rainy month. The Amazon coastal zone is subject to a high organic matter supply due to high mangrove productivity and river inputs (Dittmar et al., 2001). This organic matter and nutrient input undergoes a strong seasonal variation, with higher influence on the coast during rainy season due to high rainfall and freshwater discharge (Aller and Stupakoff, 1996), which might directly affect Nematoda assemblage.

Significant differences between periods were indicated by PERMANOVA and also by the graphic configuration of the non-metric ordination analysis (nMDS) although nMDS showed a mixture of samples between periods. This indicates that climatic period is a structuring factor of nematofauna on Caixa d'Água beach. Regarding horizontal nematofauna structure, two associations in the nMDS graph can be observed, which are related to exposure caused by the ascent and descent of the tide. The first association, related to the stations closer to the high tide mark (S1 and S2) is an assemblage characterized by undergoing an extreme desiccation, since, as mentioned above, these two stations are exposed to sunlight for a longer period. Hence, desiccation that occurs in this region of the intertidal zone might affect Nematoda, and might cause the absence of some more sensitive genera, especially in the dry month. The second association, comprised of the three stations closer to the low tide mark (S3, S4, and S5), is a community associated with the middle intertidal zone and the region of the beach that is dry for a shorter period. Therefore, temperature in these regions is relatively more constant (Gheskiere et al., 2004) and desiccation is lower, especially in the station closer to the low tide mark.

Considering vertical structure, PERMANOVA also indicated significant differences between sediment layers and the graphic configuration of the non-metric ordination analysis (nMDS) showed that Nematoda association in the lower sediment layer $(5-10 \mathrm{~cm})$ is more differentiated than that of other sediment layers $(0-2$ and $2-5 \mathrm{~cm})$. According to Ott (1972), lower sediment layers are characterized by stable environmental parameters, low concentrations (or even absence) of oxygen, and high $\mathrm{H}_{2} \mathrm{~S}$ concentration. According to the same author, animals that dwell in these layers seem to be adapted to tolerate this harsh and anaerobic environment, and maintain their populations there, but do not necessarily depend on it (Ott, 1972). However, they show lower tolerance to the variations in environmental parameters that occur in the upper sediment layers (Ott, 1972), which might explain the singular nematofauna structure in the lower sediment layers of the present study.

In our results we found that organisms have different distribution patterns in the sediment, both horizontally and vertically. On the other hand, seasonally, rainfall is the main structuring factor of fauna. Meiofauna communities and Nematoda assemblages showed changes in their horizontal and vertical distribution patterns according to different months/climatic periods (rainy $x$ dry), thus emphasizing that there is also seasonality on tropical macrotidal beaches. Some distribution patterns of organisms already known from microtidal beaches were found in this study, particularly in the rainy period, e.g. higher meiofauna density in the middle intertidal and decreased density in lower sediment layers. However, there were also differentiated patterns, even when compared to macrotidal beaches of temperate regions, such as increased Nematoda richness towards the low tide mark. These differential patterns found made it evident that tropical macrotidal beaches have differentiated characteristics and this singularity influences the distribution pattern of the interstitial fauna.

\section{ACKNOWLEDGMENTS}

Samplings were conducted in the scope of the project "Modificações na estrutura das associações bentônicas em resposta a variações morfodinâmicas em praias arenosas amazônicas" [Changes in structure of benthic associations in response to morphodynamic variations on Amazon sandy beaches] and were funded by $\mathrm{CNPq}$ (Conselho Nacional de Pesquisa [National Research Council]). The first author is grateful to the program of scientific initiation scholarship PIBIC-UFPA (Program of Scholarships to undergraduate students of the Federal University of Pará) and to FAPESPA (Fundação de Amparo à Pesquisa do Estado do Pará [Research Support Foundation of the state of Pará]) for granting the scholarships. Thanks also to the anonymous reviewers for their comments, which helped us to improve the manuscript. 


\section{REFERENCES}

ALBUQUERQUE, E. F., PINTO, A. P. B., PEREZ, A. A. Q. \& VELOSO, V. G. 2007. Spatial and temporal changes in interstitial meiofauna on a sandy ocean beach of south America. Brazilian Journal of Oceanography, 55, 121-131.

ALLER, J. Y. \& STUPAKOFF, I. 1996. The distribution and seasonal characteristics of benthic communities on the Amazon shelf as indicators of physical processes. Continental Shelf Research, 16, 717-751.

ALONGI, D. M. 1987. Intertidal zonation and seasonality of meiobenthos in tropical mangrove estuaries. Marine Biology, 95, 447-458

ANSARI, Z. A. \& PARULEKAR, A. H. 1993. Distribution, abundance and ecology of the meiofauna in a tropical estuary along the west coast of India. Hydrobiologia, 262, 115-126.

ARMENTEROS, M., RUIZ-ABIERNO, A., FERNÁNDEZ-GARCÉS, R., PÉREZ-GARCÍA, J. A., DÍAZ-ASENCIO, L., VINCX, M. \& DECRAEMER, W. 2009. Biodiversity patterns of free-living marine nematodes in a tropical bay: Cienfuegos, Caribbean Sea. Estuarine, Coastal and Shelf Science, 85, 179-189.

ARMONIES, W. \& REISE, K. 2000. Faunal diversity across a Sandy shore. Marine Ecology Progress Series, 196, 49-57.

ATAIDE, M. B., VENEKEY, V., ROSA-FILHO, J. S. \& SANTOS, P. J. P. 2014. Sandy reefs of Sabellaria wilsoni (Polychaeta: Sabellariidae) as ecosystem engineers for meiofauna in the Amazon coastal region, Brazil. Marine Biodiversity, 44, 403-413.

COULL, B. C. 1988. The ecology of marine Meiofauna. In: HIGGINS, R. P., THIEL, H. (eds.) Introduction to the Study of the Meiofauna. Washington: Smithsonian Institute Press.

COULL, B. C. 1999. Role of meiofauna in estuarine soft-bottom habitats. Australian Journal of Ecology, 24, 327-343.

COULL, B. C. \& BELL, S. S. 1979. Perspectives of marine meiofaunal ecology. In: LIVINGSTOM, R. J. (eds.) Ecological Processes in Coastal and Marine Systems. New York: Plenum Publishing Corporation.

COULL, B. C. \& CHANDLER, G. T. 1992. Pollution and meiofauna: field, laboratory, and mesocosms studies. Oceanography and Marine Biology An Annual Review, 30, 191-271.

DE GRISSE, A. T. 1969. Redescription ou modification de quelques techniques utilisés dans l'étude des nématodes phytoparasitaires. Mededelingen Rijksfakulteit Landbouwwetenschappen Gent, 34, 351-369.

DE LEY, P. \& BLAXTER, M. L. 2004. A new system for Nematoda: combining morphological characters with molecular trees, and translating clades into ranks and taxa. Nematology Monographs and Perspectives, 2, 633-653.

DITTMANN, S. 2000. Zonation of benthic communities in a tropical tidal flat of North-east. Australia. Journal of Sea Research, 43, 33-51.

DITTMAR, T., LARA, R. J. \& KATTNER, G. 2001. River or mangrove? Tracing major organic matter sources in tropical Brazilian coastal waters. Marine Chemistry, 73, 253-271.

ELMGREN, R. 1973. Methods of sampling sublittoral soft bottom meiofauna. Oikos, 15, 112-120.

ELMGREN, R. 1975. Benthic meiofauna as indicator of oxygen condition in the Northern Baltic proper. Merentutkimuslait Julk, 239, 265-271.
FONSECA-GENEVOIS, V., SANTOS, G. A. P., CASTRO, F. J. V., BOTELHO, A. P., ALMEIDA, T. C. M. \& COUTINHO, R. 2004. Biodiversity of marine nematodes from an atypical tropical coastal area affected by upwelling (Rio de JaneiroBrazil). Meiofauna Marina, 13, 37-44.

GHESKIERE, T., HOSTE, E., KOTWICKI, L., DEGRAER, S., VANAVERBEKE, J. \& VINCX, M. 2002. The sandy beach meiofauna and free-living nematodes from De Panne (Belgium). Bulletin Koninklijk Belgisch Instituut Natuurwetenschappen, 72, 43-49.

GHESKIERE, T., HOSTE, E., VANAVERBEKE, J., VINCX, M. \& DEGRAER, S. 2004. Horizontal zonation patterns and feeding structure of marine nematode assemblages on a macrotidal, ultra-dissipative sandy beach (De Panne, Belgium). Journal of Sea Research, 52, 211-226.

GIERE, O. 2009. Meiobenthology: the microscopic motile fauna in aquatic sediments, Berlin, Springer-Verlag.

GINGOLD, R., MUNDO-OCAMPO, M., HOLOVACHOV, O. \& ROCHA-OLIVARES, A. 2010. The role of habitat heterogeneity in structuring the community of intertidal free-living marine nematodes. Marine Biodiversity, 157, 1741-1753.

GOMES, T. P. \& ROSA-FILHO, J. S. 2009. Composição e Variabilidade Espaço-Temporal da Meiofauna de uma Praia Arenosa na Região Amazônica (Ajuruteua, Pará). Iheringia Serie Zoológica, 99, 210-216.

HEIP, C., VINCX, M., SMOL, N. \& VRANKEN, G. 1982. The Systematics and Ecology of Free-living Marine Nematodes. Helminthological Abstracts Series B, Plant Nematology, 51, $1-31$.

HEIP, C., VINCX, M. \& VRANKEN, G. 1985. The Ecology of Marine Nematodes. Oceanography and Marine Biology an Annual Review, 23, 399-489.

HODDA, M. 2007. Phylum Nematoda. Zootaxa, 1668, 265-293.

HOURSTON, M., WARWICK, R. M., VALESINI, F. J. \& POTTER, I. C. 2005. To what extent are the characteristics of nematode assemblages in nearshore sediments on the west Australian coast related to habitat type, season and zone? Estuarine, Coastal Shelf Science, 64, 601-612.

INGOLE, B. S. \& PARULEKAR, A. H. 1998. Role of salinity in structuring the intertidal meiofauna of a tropical estuarine beach: field evidence. Indian Journal of Marine Science, 27, 356-361.

INMET. (Instituto de Meteorologia). 2018. Dados de pluviosidade. Available at: www.inmet.gov.br (Accessed on: 12 February 2018).

JANSSON, B. O. 1968. Quantitative and experimental studies on the interstitial fauna on four Swedish sandy beaches. Ophelia, 5, 1-71.

KOTWICK, L., TROCH M. D., URBAN-MALINGA, B., GHESKIERE, T. \& WESLAWSKI, J. M. 2005. Horizontal and vertical distribution of meiofauna on sandy beaches of the North Sea (The Netherlands, Belgium, France). Helgol Marine Research, 59, 255-264.

MARIA, T. F., ESTEVES, A. M., SMOL, N., VANREUSEL, A. \& DECRAEMER, W. 2008. Nematodes from sandy beaches of Guanabara bay, Rio de Janeiro, Brazil. Biociências, 16, 92-103.

MARIA, T. F., VANAVERBEKE, J., ESTEVES, A. M., DE TROCH, M. \& VANREUSEL, A. 2012. The importance of biological interactions for the vertical distribution of nematodes in a temperate ultra-dissipative sandy beach. Estuarine, Coastal and Shelf Science, 97, 114-126. 
MARIA, T. F., VANAVERBEKE, J. GINGOLD, R., ESTEVES, A. M. \& VANREUSEL, A. 2013. Tidal exposure or microhabitats: what determines sandy-beach nematode zonation? a case study of a macrotidal ridge-and-runnel sandy beach in Belgium. Marine Ecology, 34, 207-217.

MARIA, T. F., SILVA FILHO, M. G., SOUZA, T. P., VANAVERBEKE, J., VANREUSEL, A. \& ESTEVES, A. M. 2018. Is the vertical distribution of meiofauna similar in two contrasting microhabitats? A case study of a macrotidal sandy beach. Journal of Experimental Marine Biology and Ecology, 502, 39-51.

MCLACHLAN, A. 1977. Composition, distribution, abundance and biomass of the macrofauna an meiofauna of four sandy beaches. Zoologica Africana, 12, 279-306.

MCLACHLAN, A. 1983. Sandy beach ecology - a review. In: McLachlan, A. \& Erasmus, T. (eds.) Sandy beaches as ecosystems. South Africa: Dr. W. Junk Publishers.

MCLACHLAN, A. \& BROWN, A. C. 2006. The ecology of sandy shores, Burlington, Academic Press.

MCLACHLAN, A. \& TURNER, I. 1994. The interstitial environment of sandy beaches. Marine Ecology, 15, 177-212.

MELO, T. P. G., ROSA FILHO, J. S. \& VENEKEY, V. 2013. Marine Nematoda from ajuruteua beach, Amazon coast, Brazil. Atlântica, Rio Grande, 35, 67-70.

MODIG, H. \& ÓLAFSSON, E. 1998. Responses of Baltic benthic invertebrates to hypoxic events. Journal of Experimental Marine Biology and Ecology, 229, 133-148.

MONTAGNA, P. A. \& KALKE, R. D. 1992. The effect of freshwater inflow on meiofaunal and macrofaunal populations in the Guadalupe and Nueces estuaries, Texas. Estuaries, 15, 307-326.

MOODLEY, L., CHEN, G., HEIP, C. \& VINCX, M. 2000. Vertical distribution of meiofauna in sediments from contrasting sites in the Adriatic Sea: clues to the role of abiotic versus biotic control. Ophelia, 53, 203-212.

MORAES, B. G., COSTA, J. M. N., COSTA, A. C. L. \& COSTA, M. H. 2005. Variação espacial e temporal da precipitação no estado do Pará. Acta Amazonica, 35, 207-217.

MORENO, M., FERRERO, T. J., GRANELLI, V., MARIN, V., ALBERTELLI, G. \& FABIANO, M. 2006. Across shore variability and trophodynamic features of meiofauna in a microtidal beach of the NW Mediterranean. Estuarine, Coastal and Shelf Science, 66, 357-367.

MUNDO-OCAMPO, M., LAMBSHEAD, P. J. D., DEBENHAM, N., KING, I. W., DE LEY, P., BALDWIN, J. G., DE LEY, I. T., ROCHA-OLIVARES, A., WAUMANN, D., THOMAS, W. K., PACKER, M. \& BOUCHER, G. 2007. Biodiversity of littoral nematodes from two sites in the Gulf of California. Hydrobiologia, 586, 179-189.

MURRELL, M. C. \& FLEEGER, J. W. 1989. Meiofauna abundance on the Gulf of Mexico continental shelf affected by hypoxia. Continental Shelf Research, 9, 1049-1062.

NICHOLAS, W. L. \& HODDA, M. 1999. The free-living nematodes of a temperate, high energy, sandy beach: faunal composition and variation over space and time. Hydrobiologia, 394, 113-127.

OLAFSSON, E. 1991. Intertidal Meiofauna of four sandy beaches in Iceland. Ophelia, 33, 55-65.

OLIVEIRA, S. M. O., PEREIRA, L. C. C. \& VILA-CONCEJOBE, A. 2014. Morphodynamic processes in a macrotidal beach in the Amazon littoral. Quaternary and Environmental Geosciences, 5, 125-136.

OTT, J. A. 1972. Determination of fauna boundaries of nematodes in an intertidal sand flat. Internationuir Revue der Gesamten Hydrobiologie und Hydrographie, 57, 645-663.
PATTNAIK, A. \& RAO, M. V. L. 1990. Composition and distribution of interstitial meiofauna of the sandy beach at Golpapur South Orissa Coast. Indian Journal of Marine Sciences, 19, 165-170.

PINTO, T. K. O. \& SANTOS, P. J. P. 2006. Meiofauna community structure variability in a Brazilian tropical sandy beach. Atlântica, Rio Grande, 28, 117-127.

PLATT, H. M. 1977. Ecology of free-living marine nematodes from na intertidal sandflat in Stragford Lough, Northern Ireland. Estuarine, Coastal and Shelf Science, 5, 685-693.

PROST, M. T. R. 1994. O litoral NE do Estado do Pará: dinâmicas atuais e aplicações do sensoriamento remoto - Municípios de Marapanim, Maracanã, e Salinópolis. Belém, CNPq.

ROCHA, C. M., FONSECA-GENEVOIS, V., CASTRO, F. J. V., BEZERRA, T. N. C., VENEKEY, V. \& BOTELHO, A. P. 2004. Environmental interactions of Batillipes pennaki (Tardigrada, Heterotardigrada) in a tropical sandy beach (Itamaraca, Pernambuco, Brazil). Meiofauna Marina, 13, 79-86.

RODRÍGUEZ, J. G., LÓPES, J. \& JARAMILLO, E. 2001. Community structure of the intertidal meiofauna along a gradient of morphodynamic sandy beach types in southern Chile. Revista Chilena de Historia Natural, 74, 885-897.

ROSA-FILHO, J. S., GOMES, T. P., ALMEIDA, M. F. \& SILVA, R. F. 2011. Benthic fauna of macrotidal Sandy beaches along a small-scale morphodynamic gradient on the Amazon coast (Algodoal Island, Brazil). Journal of Coastal Research, 64, 435-439.

SANDULLI, R. \& DE NICOLA-GIUDICI, M. 1991. Responses of meiobenthic communities along a gradient of sewage pollution. Marine Pollution Bulletin, 22, 463-467.

SCHRATZBERGER, M. \& WARWICK, R. M. 1998. Effects of the intensity and frequency of organic enrichment on two estuarine nematode communities. Marine Ecology Progress Series, 164, 83-94.

SHARMA, J. \& WEBSTER, J. M. 1983. The abundance and distribution of free-living nematodes from two Canadian Pacific beaches. Estuarine, Coastal and Shelf Science, 16, 217-227.

SNELGROVE, P. V. R. \& BUTMAN, C. A. 1994. Animal-sediment relationships revisited: cause versus effect. Oceanography and Marine Biology, 32, 111-117.

SOUZA-FILHO, P. W. M., LESSA, G. C., COHEN, M. C. L., COSTA, F. R., LARA, R. J. 2009. The subsiding macrotidal barrier estuarine system of the eastern Amazon coast, northern Brazil. In: DILLENBURG, S. F. \& HESP, P. A. (eds.) Geology and geomorphology of Holocene coastal barriers of Brazil. Springer: Berlin \& Heidelberg.

VANAVERBEKE, J., BEZERRA T. N., BRAECKMAN, U., De GROOTE, A., DE MEESTER, N., DEPREZ, T., DERYCKE, S., GILARTE, P., GUILINI, K., HAUQUIER, F., LINS, L., MARIA, T., MOENS, T., PAPE, E., SMOL, N., TAHERI, M., Van CAMPENHOUT, J., VANREUSEL, A., WU, X. \& VINCX, M. 2016. NeMys: World Database of Free-Living Marine Nematodes. Available at: http://nemys.ugent.be (Accessed on: 2016 Apr 5).

VENEKEY, V., SANTOS, P. J. P. \& FONSÊCA-GENEVOIS, V. G. 2014. Effect of Environmental Factors on Intertidal Nematoda in a Tropical Sandy Beach (Tamandaré Bay, Pernambuco, Brazil). Journal of Coastal Research, 30, 785-794.

WARWICK, R. M., PLATT, H. M. \& SOMERFIELD, P. J. 1998. Free-living marine nematodes (Part III: Monhysterids). Shrewsbury, Field Studies Council.

WIESER, W. 1953. Die Beziehung zwischen Mundlohlengestalt, Ernahrungsweise und Vorkommen beifreilebenden marinen Nematoden. Arkiv fur Zoologie, 4, 439-484. 